\title{
Personalities Behind the Development of PAIS
}

Miss Manley is supervising business librarian, Newark Public Library.

$\mathrm{T}$

HIS year, PAIS is forty years old. The subscribers to its weekly Bulletin, ${ }^{2}$ its cumulations and its annual volumes have grown steadily since the first forty were enroled in I9I4. The quantity of material to which it is the key has increased even more. The annual volumes have expanded from the first in 1915 with its 344 pages to the current volume numbering 827. Yet PAIS is perhaps unique among library expenses in that the cooperating libraries are still paying \$IOO annually, as they did when the service first appeared in printed form in 1915 .

PAIS is a notable achievement, invaluable to libraries large and small. Yet it is probably one of the least discussed of library projects. In a professional world where hundreds of pages are devoted to the pros and cons and many facets of any library development, this quiet but steady progress is in itself a phenomenon. To what can such progress be attributed?

Frankly, PAIS can be considered the lengthened shadow of three men: John A. Lapp, Charles C. Williamson and Rollin A. Sawyer. Each one has been the directing head at a time when his special gifts have been of infinite value to the development of a great bibliographic tool. Each

1 Paper presented at the meeting of the American Library History Round Table, Chicago, Ill., February 2, ${ }_{2}^{195}$ Bulletin of the Public Affairs Information Service. one has given unsparingly of his ability and interest. The debt owed them by the library profession is great.

When we read in "Who's Who" of the long list of achievements of the distinguished labor arbitrator, Dr. John A. Lapp, it comes as a surprise to realize that we owe this major index to his efforts. We can be proud that in those early years he saw the outlines and ramifications of an increasing problem and through his leadership a solution was found.

PAIS was first discussed in 1910. A number of elements had combined to focus attention on the stream of special publications for which there was no general listing or guide. Legislative reference libraries had come into being. The six years' development of the Newark Business Library had helped to focus attention on many sources of information hitherto receiving little library attention. The Special Libraries Association, formed in I909, had brought together a group of lively minds and afforded a meeting place for those who had had occasion to realize both the amount of specialized information in print and its relative inaccessibility.

In such a climate, Dr. Lapp, then with the Indiana State Legislative Reference Bureau brought up for discussion at the I9Io meeting of the Special Libraries Association the possibility of an index to public affairs publications. As chairman of the new Association's Public Affairs Committee, he stressed the need for such an index covering city and state reports, those from 
many national associations in the field of public affairs, and the countless other sources of information untouched by the existing indexes. At succeeding conferences there was further discussion of the needs, but no method of meeting the problem was defined.

At the Kaaterskill Conference in I9I 3 no formal action was taken by the Special Libraries Association, but a group including Guy Marion, Arthur D. Little, Inc., Boston; John Cotton Dana, Newark Public Library; Robert H. Whitten, Public Service Commission, New York; George Godard, Connecticut State Library; Daniel Handy, Insurance Library Association, Boston; H. H. B. Meyer, Library of Congress, and Dr. Lapp, in informal discussion felt that no more time should pass without action. Dr. Lapp said, "The way to begin is to begin" and that if the major special libraries would each pledge $\$ 25$ annually, and would cooperate in supplying material, he would undertake the work of assembling information at the Indiana Legislative Reference Bureau and distribute the lists in mimeographed forms with the bibliographical notes. As Dr. Lapp was also editing Special Libraries at that time, he had a supplementary source of material. He believed that the benefit to the Indiana $\mathrm{Bu}$ reau in becoming the clearing house for the materials justified the use of staff time in the project. The payments from the cooperators covered the mimeographing and distribution costs. Lillian Henley of the staff of the Legislative Reference Bureau took the major job of managing the work and Ethel Cleland, then librarian of the Bureau, gave much assistance. Dr. Lapp took as his share of the venture the determination of types of material and priorities. It was on this basis that PAIS first came in to being and went on for one year.

At this point another of our library geniuses came into the picture. H. W. Wilson with his gift for the development of the current printed index saw the potentialities of PAIS and went to Dr. Lapp with a proposal that the material be printed cumulatively in the form of other Wilson publications. He proposed to take it over as a cooperative enterprise and publish it on a "cost plus" basis. The cooperators agreed and Dr. Lapp was enlisted by Mr. Wilson to go to White Plains to help organize the new bulletin and to secure the minimum number of cooperators. Orrena Louise Evans became the first editor. Expenses were covered by the 70 or so cooperators who were now paying \$Ioo a year.

With the printed weekly bulletins and the frequent cumulations, PAIS became even more useful to the cooperators. An Advisory Committee was established consisting of Dr. Lapp, George S. Godard and Charles C. Williamson, then librarian of the New York Municipal Reference Library. Under the editorship of Miss Evans and later Lillian Henley, the growth was satisfying. Innumerable problems incident to the development of the publication were solved and the format that has proved so satisfactory was evolved. Dr. Lapp's interest was unabated and he served as a member of the Advisory Committee, but his active direction was discontinued after he had done this major task of organization. Dr. Charles C. Williamson became chairman.

Dr. Williamson had served on the Advisory Committee of PAIS since I9I5, but while he was Municipal Reference Librarian, his interest in the growth of PAIS was not too acute. But when he became chief of the New York Public Library Economics Division in I919, he had immediate reason to become more deeply interested. From the vantage point of the Economics Division two problems became clear. Comparatively few of the materials that should be 
indexed in PAIS were flowing naturally into the Wilson offices for use in such an index. On the other hand, the New York Public Library had an abundant intake of valuable material from all over the world, both free and purchased. In normal library processes such material could not be as fully analyzed as it should be for good service. In Dr. Williamson's eyes a desirable method for meeting such a situation was the transference of the editorial office of PAIS from the H. W. Wilson Company to the Economics Division. This would give the editor a chance to select material for inclusion from the wealth of publications received by the library. The prompt analysis and listing of such material in PAIS would not only give the users of PAIS prompt information on hundreds of publications, it would give the New York Public Library a much more detailed and promptly issued printed guide to its resources in this field than could be financially and administratively possible under any other circumstances.

At this time the Advisory Committee consisted of Dr. Lapp, Mr. Godard, Mr. Hicks, Mr. Wheeler and Dr. Williamson. Service on the Committee had been a pleasant and not too strenuous responsibility. Dr. Williamson's new slant on the future possibilities of PAIS changed this for a while. The revolutionary idea led to much discussion and produced some masterly and detailed memoranda. It was not surprising that the editor and the publisher were disturbed at the possibility of difficulties developing in what had become a smoothly running operation. Where the library was concerned Dr. Williamson had other problems. He had to convince the naturally dubious Director, Mr. Anderson, that the precedent set by letting him run a "commercial" service in the library building would not be dangerous. Too, the Acquisi- tions Department of the library could not be expected to be altogether happy about letting PAIS have the first chance to go over the material that came to the library. However, in time Mr. Anderson was convinced. The Advisory Committee and the publisher discussed all angles. Eventually the soundness of the Williamson proposals was recognized and the plan accepted. As a result, the library cooperators in PAIS now have the tremendous advantage of consulting what amounts to an acquisition list of the New York Public Library's resources in the fields of economics and public affairs. Too, the opportunity for selective indexing of the extensive collection of periodicals in the same fields has immeasurably increased the value of the Bulletin.

Another important step taken at this time as a result of Dr. Williamson's study was a clarification of the organization of PAIS itself. Until that time it had operated on an informal basis with no clearly defined lines of responsibility. Just who decided what had never been stated and machinery for making suggestions by the cooperators effective, for example, with the publisher was nonexistent. With this general study of the status of PAIS it was apparent that its future progress demanded some definite basis by which the cooperators could, through their representatives, the Advisory Committee, control the service. As a result of this study, Dr. Williamson, as chairman, was asked to draw up articles of agreement and after their study by the members and adjustment of details, they were submitted to the cooperators for vote. These articles have since then been the basis for the operation of PAIS. Briefly stated, they outline the procedure by which the cooperators who are the libraries paying \$IOO for the service, elect the Publications Committee of five members and that Committee, formerly the Advisory Commit- 
tee, is responsible for the management of PAIS.

In the development of PAIS, Dr. Lapp was responsible for originating the plan and for starting the service on its long and successful career. Dr. Williamson, in the period in which he guided its destinies, had greatly expanded the usefulness of the service by bringing the editorial work to the New York Public Library. Under his auspices the formal organization of PAIS had been clarified. Annual revenues for PAIS had grown from $\$ 7,378$ in 1915 to $\$ 12,794$ in 1919. PAIS was now a well established entity.

When Rollin Sawyer became chief of the Economics Division in 1919 he succeeded Dr. Williamson as chairman of the Publications Committee for PAIS, a position he has held since that time. The editorial policies had been established, a formal organizational procedure had been defined. But in 1923 another major change took place. Until then, the financial management had been in the hands of the $\mathrm{H}$. W. Wilson Company as publishers. At that time Mr. Wilson asked to be relieved of the responsibility and it was assumed by the Publications Committee while the $\mathrm{H}$. W. Wilson Company continued as printer. This shift in management was a logical move as it placed all managerial responsibilities with the Committee. Since I923, the chairman has been editorial advisor, general manager, salesman and bookkeeper, a combination of duties carried out with remarkable success by Mr. Sawyer.

PAIS, a library sponsored and library managed project, is a business success. A non-profit organization, it has published for forty years a bulletin which has become a foundation reference tool in all but the smallest libraries. In 1953 its 663 contributors received weekly bulletins of 24 pages covering some 700 entries each and an an- nual of 827 pages. This has been done without any increase in the annual contribution of \$IOO, first established in I9I5. In this period the cost value of the subscription list has grown to be four times as large, or from $\$ 12,367$ to $\$ 53,430$. The revenue for 1953 covered a payroll of $\$ 3 \mathrm{I}, \mathrm{I} 74$ and printing costs of $\$ 20,910$ as compared with the corresponding costs of $\$ 5,700$ and $\$ 4,500$ when Mr. Sawyer took over in I92 I. This change can be attributed in part to a growing understanding by librarians of the need for this tool. To a far greater extent it must be attributed to the quiet systematic work of its able chairman.

To the editors who, in the forty years of its growth, have facilitated the use of the flood of publications, the library world is greatly indebted also. The list includes only seven names, but their contributions are diversified. While Lillian Henley edited the mimeographed sheets that appeared when PAIS was issued from Indianapolis, Orrena Louise Evans was the first editor of the printed bulletin published by the H. W. Wilson Company. The first annual cumulation appeared with Miss Evans as editor in 1915 and in its introduction she summarizes the development of PAIS and the problems met in its progress. She passes lightly over the difficulties but they must have been many. Although Miss Evans had the great advantage of drawing on the experience of the $\mathrm{H}$. W. Wilson Company in the solution of indexing and format problems, there were still the questions created by the special peculiarities of the varied types of material included in PAIS. It is a tribute to her powers of organization and editorial ability that the current format of PAIS so closely follows the pattern which she set.

But editorial problems were not the only ones encountered in these early days. A 
system of obtaining material to list had to be built up almost from the bottom. In this the cooperators were supposed to assist but with the loose organization it was natural that their aid was intermittent. Much correspondence was required to insure accuracy in the entries. All in all, the first volume can be considered a monument to Miss Evans' diligence and enterprise. In writing of these early days, Miss Evans says: "Your letter has set me thinking of those early days of Public Affairs Information Service when the H. W. Wilson Company was housed in a big garage on Mamaroneck Avenue in White Plains. The front end of the building had a second floor and this is where PAIS was housed. From the editorial and printing standpoints the $\mathrm{H}$. W. Wilson Company was a wonderful place for PAIS, as was the access to conventional books and periodicals; but for the real purpose for which PAIS was organized-to call attention to pamphlets, reports, ephemeral material, notices of meetings, digests of legislation, and the like -it was anything but a fertile field. I remember what a feeling of helplessness $I$ had in trying to issue a Bulletin without access to the needed information. $\mathrm{Mr}$. Lapp and his Bureau of Legislative Information were most helpful in the early days in sending notices of information to be included.

"Our staff began busily writing letters to government agencies (federal, state and local), universities, associations and other sources and received enough material to issue the Bulletin from week to week. But I used to wish the work could be done in New York where access to publishers and libraries would make it possible to cull only the best. When I learned the compilation of material for the Bulletin was to be taken to the New York Public Library I considered it a wise move.
"During my association with PAIS the form of publication was worked out, decision was made to include the various key lists in the front of the Annual, editorial policy and office routine adopted, and a start made in turning the vast tide of ephemeral material toward the $\mathrm{H}$. W. Wilson Company for listing. Mr. Wilson and the editors of the other $\mathrm{H}$. W. Wilson publications were most helpful, both by making their review publications available and by suggestions as to form and methods. Mr. Lapp made frequent visits to New York and came out to see how PAIS was getting along. He was full of optimism and enthusiasm and had a keen grasp of the field. His advice and suggestions were of the greatest assistance."

After two years as editor, Miss Evans left to become librarian of the Bureau of Public Roads in Washington, a position with which we all associate her. Lillian Henley, who had handled the preliminary issues of the Bulletin, came on from Indianapolis to be the next editor. In her first annual, 1916, she pays tribute to Miss Evans for her work. Miss Henley in turn dealt with the problems of expanding the content of the Bulletin until I9I9, a period in which publishing problems diminished with the close cooperation possible through its location at the Wilson plant.

Experimentation in different lines was tried in this period and it was at this time that one noble experiment was finally proved to be impractical. When PAIS was first projected, one service attempted was its use as a clearing house for these special publications so that cooperators could use the Bulletin as a checklist placing orders through PAIS. Such work had clogged the machinery of the publication to such an extent that the prompt listing of useful material was impossible. With the general 
reorganization that took place and the study of the work of PAIS, it was decided to eliminate all order work for cooperators and confine the efforts of the PAIS staff to the development of the Bulletin itself. As a result there was immediate improvement in the varied content of the Bulletin and the promptness with which material was listed.

When in I9r9 the editorial offices of PAIS were moved from the H. W. Wilson Company to the Economics Division of the New York Public Library, Miss Henley left to become research secretary of the National Municipal League. Alice L. Jewett took over in her place and served as editor for two years. This again was a period of adjustment. The editor now had the advantages of contact with the resources of a large reference library. Through the courtesy of the library, incoming books, pamphlets and documents were examined each day so that everything which fell within the scope of the service was immediately available. Too, there was the great advantage afforded in the opportunity to examine many economic and trade periodicals not elsewhere indexed. This system made possible not only greater promptness in listing material, but also much more discriminating selection than was possible when money and so much of the editor's time were consumed in acquiring material which, once listed, was of no further use to PAIS. The great advantage of prompt examination, held to this day, has meant that the weekly bulletins can carry information on publications received shortly before going to press.

Under these three editors, the problems in the development of PAIS as a serviceable index were to a great extent solved. Under Miss Evans and Miss Henley the format was evolved and the scope of the entries was decided. In Miss Jewett's term, the problems of working with the facilities of the library were encountered and a procedure satisfactory to the library personnel and effective for PAIS was found. The path for future editors to follow was clearly defined.

Miss Jewett served as editor from 1920 to 1922 and Harriet Burcholdt, who followed her, from I922 to 1925 . Then came the long period of service as editor of Mary Elizabeth Furbeck, who kept the service moving smoothly for twenty-two years, I925 to 1947. By now the problems of organization and scope had been solved. Close contact with the users of PAIS was invaluable in noting new trends and adjusting headings and entries to changing conditions. Rollin Sawyer with his wide knowledge of the field and intense interest in the development of the service, was at hand for consultation. The chief objective of the service now was adequate coverage and prompt publication. Miss Furbeck, quiet, systematic and persevering, was well equipped for the work that she carried on so satisfactorily until ill health forced her retirement in 1945 .

The position of editor of PAIS is not an easy one to fill. While it offers the advantage of at least a brief opportunity to scan the varied publications growing out of the changing trends and demands of the whole field of economics and public affairs, it calls for the patience to participate in and oversee an immeasurable amount of detail. Yards of galley press must be read and thousands of entries must fall into their appropriate place. While the machinery for handling this detail is established, the human element is always present and its weakness must be anticipated. Only those with special qualities can spend long hours happily engaged in this work and the library world has been fortunate that so far PAIS has been able to find people of this calibre. 
When Miss Furbeck retired, her long time associate, May Mellinger, retired also and the chairman had some difficult years in continuing a smoothly running publication. The shortage in library personnel in the years from I 945 on made it difficult to fill the position. Fortunately, Mary E. Bartley, who had come up through the ranks of PAIS proved to be adaptable and resourceful. PAIS continued to prove its worth, but with many hectic moments for the chairman and for Miss Bartley as editor. In 1952 Miss Bartley asked to be released as soon as a successor could be found, and after some months, the present editor, Robert S. Wilson was appointed. With a background of professional training, with experience in the Acquisitions Department of the New York Public Library, and with his real interest in the opportunity to note the progress of world affairs through the flow of print, the editorial future of PAIS has brightened considerably and the Publications Committee and its Chairman may feel more at ease about the immediate future.

In the growth of PAIS the respective chairmen and editors have of necessity carried the full burden but the parts played by the other members of the Committee and by the cooperators have their important aspects. The cooperators with their substantial financial contribution through the years made the growth of PAIS possible. In their varying degrees of expressed interest they have helped to develop the scope and editorial value of the service. Each year they receive a report of progress of their project and each year they vote for one member of the Publications Committee of five serving for a term of five years. Always the chairman and the different members of the Committee have welcomed suggestions for the development of the service and to the extent they have been forthcoming the cooperators have made direct contributions to the increased service of the bulletin.

The members of the Publications Committee have been distinguished for length of service rather than for their number. Of the original group of three, Dr. John A. Lapp served from the beginning until 1929. His contribution to the service both as the first chairman and as a member of the Committee cannot be measured. Dr. Williamson, who clarified the organization of PAIS and brought it to the New York Public Library, served until he left that institution for the Rockefeller Foundation in I 92 I. George S. Godard, State Librarian of Connecticut, the last of the original three, served until his death in 1936. While less active than the other two, his thoughtful consideration of the organizational problems and his sound advice made his service of special value.

At the Louisville meeting of ALA in I9I 7 the original committee of three was expanded to five and Joseph L. Wheeler, then at Youngstown, and Frederick C. Hicks, at that time law librarian of Columbia University, were asked to serve. Mr. Wheeler served until 1922 when he resigned because of ill health. In $1929 \mathrm{Mr}$. Wheeler again came on the committee in place of Dr. Lapp, whose many other activities had forced him to give up the contact with PAIS. Mr. Wheeler brought to his service on the Committee the experience derived in a medium-sized library such as Youngstown and again in the large Enoch Pratt Free Library in Baltimore. Writing of his contacts with PAIS he says:

I was librarian at Youngstown, a hustling industrial city of smoke and steel, where the word "library" had been associated in the public mind with Shakespeare and children's books, rather than as a vital help in solving the daily vocational, civic and personal problems of the adult Tom, 
Dick and Harry. PAIS was a tremendous lift, a new well oiled key to a vast realm of everyday community topics, and a stimulus to every library to get busy, beat the bushes, and introduce library materials and services to great groups of busy men who had no idea it could help them. I still think PAIS should have ten times as many subscribers, and that the libraries using it should keep up a stream of publicity about it ...

Mr. Hicks served for- slightly more than thirty years as a member of the Publications Committee, most of the time as its secretary. Always methodical and thorough, his contributions were greatly missed when ill health forced his retirement in $\mathbf{I} 948$. Though seriously handicapped, his interest is still keen and his generosity in sending on his PAIS files is responsible for much of the data presented here.

When Mr. Wheeler resigned from the Publications Committee in 1922, he was succeeded by Dorsey W. Hyde, Jr., at that time engaged in civic research for the $A$ merican City, and later librarian of the $\mathrm{New}$ York Municipal Reference Library. In these and later positions he both used and was useful to PAIS. Now in the retirement which brought his resignation from PAIS in 1952, his recollection of what PAIS meant in his work is still as keen. In writing of this he says:

In New York City I called PAIS to the attention of various city officials who learned for the first time of the research background of various civic problems. While with the National Chamber I compiled some sixty-odd technical and statistical reports on major civic problems, which were distributed to requesting chambers of commerce throughout the country. The compilation of these reports was made possible by the use of PAIS. Because of PAIS I was able to write reports with information no where else obtainable. All who heard it congratulated us upon the performance of a widely needed public service.
So for its first twenty-odd years, only seven people, the three successive chairmen, Dr. Lapp, Dr. Williamson, and Mr. Sawyer and four Committee members, Mr. Godard, Mr. Wheeler, Mr. Hicks and Mr. Hyde were responsible for the administration of PAIS. The death of Mr. Godard in 1936 and my appointment as his successor were the first major changes since the appointment of Mr. Sawyer in I $92 \mathrm{I}$ and Mr. Hyde in 1922. Now with the appointment of Donald Clark, associate librarian, Baker Library, Harvard, in 1948, Charles F. Gosnell, state librarian, New York, in 1949, and Eileen Thornton, librarian, Vassar College, in 1952, succeeding respectively, Mr. Wheeler, Mr. Hicks and Mr. Hyde, the founding fathers are no longer at the helm. But the years of experience of the chairman, Rollin Sawyer and the regard for the standards set for PAIS held by the Committee members, insures its continuance along the lines that have given so much satisfaction.

So much for the personalities that have guided and produced PAIS. Has its use increased with the same steady growth? On this, comments from two of the earliest subscribers throw light. In speaking of PAIS, Margaret Bonnell, librarian of the Metropolitan Life Insurance Company Library, one of the great special libraries of the country, says:

Our Insurance Research librarian tells me she found PAIS extremely useful in library research for a company staff which made an extensive study of Social Insurance and prepared a series of monographs published by the company in the I930's. She has continued to use it for reference questions involving Social Insurance and Pensions-especially to keep informed about current legislation and International Labour Office reports. In reference work for the Business Research bureaus of our company we rely heavily on PAIS for (Continued on page 276) 
to which successful alternative cataloging methods, e.g. printed indexes, may be used. Others maintain that the catalog administrator alone is aware of the commitments on the time of his staff that are made by such decisions, and that he knows better how much of his staff's time is needed for other work. Others maintain that it makes little difference who decides, as long as the deciding officer keeps in mind both (I) needs of readers in terms of ability to find books under the specific class numbers for their contents, and (2) the effect of such decisions on the catalog department and on its ability to perform with maximum efficiency.

It is to be expected that if the decision is left to those in charge of readers' services, more sets will be scattered than if the decision is left to those in charge of technical services. Some high-level library executives may wish to make the decision themselves.

The decision to scatter or not to scatter monographs in series is one of sufficient importance and has such far-reaching effects on library processing costs as to warrant the personal attention of administrators at the cataloging level, technical processes level or top-administrator level. Every such administrator should have or acquire a thorough understanding of how and why the decisions are reached in his library, and of the effects of the prevailing policy.

\section{Personalities Behind the Development of PAIS}

\section{(Continued from page 27o)}

information in fields of wholesale and retail trade and finance.

Its use from another angle is reflected in a letter from Esther Schlundt, head of the Readers Division of Purdue University Libraries:

With the growth of our graduate school program we have found that the demand for the special services which PAIS can render has increased and that we now also acquire many more of the special studies and series which are included in this index. From a practical point of view we consider it a very satisfactory social science index and invaluable when it comes to finding pertinent state, federal, and now United Nations documents from a subject approach. We, of course, use with great frequency, the Directory of Publications and Organizations as well as the bibliographical data given in the Key to Peri-

\section{odical References.}

I well remember having helped a student in aeronautical engineering try to find material on the transportation of pharmaceuticals by air. We searched through the engineering and aviation literature indexes with little success and then went to PAIS to find there just about what he wanted in a Wayne University Study in Air Transportation on the air cargo potential in drugs and pharmaceuticals.

While the chairmen of the Publications Committee have carried the administrative burden, and the demands on the members of the Committee have been slight, we find an enduring satisfaction in our relationship to a financially sound institution that quietly and without fanfare has served so effectively as an aid to research. 